\title{
Edukacja zdrowotna pacjentów z chorobami układu sercowo-naczyniowego
}

\section{Health education in patients with cardiovascular diseases}

\author{
Piotr Michalski ${ }^{1}$, Agata Kosobucka ${ }^{2}$, Marta Nowik ${ }^{1}$, Łukasz Pietrzykowski ${ }^{1}$, \\ Anna Andruszkiewicz ${ }^{1}$, Aldona Kubica ${ }^{1}$
}

${ }^{1}$ Katedra i Zakład Promocji Zdrowia Uniwersytetu Mikołaja Kopernika w Toruniu, Collegium Medicum w Bydgoszczy

${ }^{2}$ Zakład Teorii Pielęgniarstwa Katedry Pielęgniarstwa Zachowawczego Uniwersytetu Mikołaja Kopernika w Toruniu, Collegium Medicum w Bydgoszczy

\section{Streszczenie}

Choroby układu sercowo-naczyniowego są główną przyczyną zgonów w Polsce oraz w pozostałych krajach Europy. Należą one do grupy chorób przewlekłych. Jak wykazują wyniki badań epidemiologicznych, zależą od występowania wielu czynników ryzyka - modyfikowalnych i niemodyfikowalnych. Do najważniejszych z grupy czynników modyfikowalnych zalicza się otyłość, hiperlipidemię, nadciśnienie tętnicze, cukrzycę, palenie tytoniu, małą aktywność fizyczną oraz czynniki psychospołeczne.

Działania edukacyjne prowadzone u pacjentów z rozpoznanymi chorobami układu sercowo-naczyniowego mają na celu wyeliminowanie lub modyfikację istniejących czynników poprzez przekazanie wiedzy na temat właściwego postępowania oraz zmotywowanie do przestrzegania wdrażanych zaleceń terapeutycznych.

Jak pokazują liczne doniesienia naukowe, wdrażanie interwencji edukacyjnych z zastosowaniem metod ustnych i pisemnych oraz złożonych programów rehabilitacyjno-edukacyjnych sprzyja podniesieniu poziomu wiedzy, co może zwiększyć efektywność zastosowanej terapii.

Słowa kluczowe: edukacja zdrowotna, choroby układu sercowo-naczyniowego

Folia Cardiologica 2016; 11, 6: 519-524

\section{Wstęp}

Choroby układu sercowo-naczyniowego stanowią istotny problem zdrowotny. Są one główną przyczyną zgonów w Polsce oraz w Europie. Raport European Heart Network z 2012 roku wskazuje, że choroby układu sercowo-naczyniowego są przyczyną 47\% wszystkich zgonów w Europie [1].

Choroba wieńcowa, podobnie jak udar mózgu czy chromanie przestankowe, jest klinicznym objawem miażdżycy, która należy do grupy schorzeń przewlekłych. Proces miaż- dżycowy jest zasadniczą przyczyną choroby niedokrwiennej serca nie tylko u osób w starszym wieku, ale także przed 45. rokiem życia [2].

Postępowanie terapeutyczne u pacjentów z rozpoznanymi chorobami układu sercowo-naczyniowego jest złożonym procesem, który nie powinien kończyć się wraz z opuszczeniem szpitala przez chorego. Jak wskazują badania Gierlotki i wsp. [3], 12\% pacjentów hospitalizowanych z powodu ostrego zespołu wieńcowego trafia ponownie do szpitala w ciągu roku, a średnio $10 \%$ umiera do roku od wypisania [3]. 
Biorąc pod uwagę wieloczynnikowość chorób układu sercowo-naczyniowego oraz wpływ stylu życia na zachowanie zdrowia, zasadne jest prowadzenie edukacji zdrowotnej w ramach profilaktyki pierwotnej i wtórnej [4].

Celem pracy był przegląd piśmiennictwa dotyczącego miejsca edukacji zdrowotnej w terapii osób z chorobami układu krążenia.

\section{Czynniki ryzyka i wiedza pacjentów}

W badaniu INTERHEART, którego wyniki okazały się istotne dla prowadzenia działań prewencyjnych z zakresu chorób sercowo-naczyniowych, wskazano na występowanie 9 niezależnych czynników odpowiadających za zawał serca. W grupie tej znalazło się 6 czynników zwiększających ryzyko i 3 czynniki mające znaczenie ochronne. Do czynników ryzyka zaliczono zaburzenia lipidowe, palenie tytoniu, czynniki psychospołeczne, otyłość brzuszną, nadciśnienie tętnicze oraz cukrzycę. W grupie czynników ochronnych znalazły się aktywność fizyczna, spożywanie warzyw i owoców oraz umiarkowane spożywanie alkoholu [5].

Wyniki długofalowej obserwacji naukowców z Mayo Clinic, obejmującej pacjentów przed 50. rokiem życia hospitalizowanych z powodu choroby wieńcowej, u których wykonano przezskórną interwencję wieńcową (PCl, percutaneous coronary interventions), potwierdzają narastające z wiekiem obciążenie klasycznymi czynnikami ryzyka sercowo-naczyniowego, takimi jak cukrzyca, otyłość, nadciśnienie tętnicze i hiperlipidemia [6].

Dotychczasowe badania prowadzone nie tylko w populacji mieszkańców Polski, ale także w innych krajach zarówno rozwijających się, jak i ustabilizowanych gospodarczo, wykazują braki w zakresie wiedzy pacjentów na temat prawidłowych zachowań zdrowotnych oraz czynników ryzyka chorób cywilizacyjnych. Pacjenci hospitalizowani z powodu chorób przewlekłych nie znali czynników ryzyka występowania choroby, jej istoty oraz zasad samoopieki i samokontroli. Problem ten dotyczy także osób, u których nie zdiagnozowano powszechnie występujących chorób przewlekłych. Pokazuje to, w jak niewielkim stopniu są rozwinięte lub jak małą skuteczność mają działania edukacyjne w pierwotnej i wtórnej profilaktyce chorób układu sercowo-naczyniowego [7-9].

Znajomość występowania czynników ryzyka choroby niedokrwiennej serca jest zróżnicowana i zależna od takich zmiennych, jak płeć, wiek, poziom wykształcenia, status ekonomiczny. Determinuje ją także występowanie chorób w rodzinie, liczba hospitalizacji i czas leczenia [10-12].

W badaniu Kozińskiego i wsp. [13] w grupie 255 pacjentów, dotyczącym poziomu wiedzy na temat czynników ryzyka chorób układu sercowo-naczyniowego, wykazano, że pojęcia "czynnik ryzyka” nie potrafi zdefiniować 6,3\% respondentów. Spośród respondentów deklarujących znajomość czynników ryzyka chorób serca 5,9\% nie wymieniło ani jednego poprawnie. Optymizmem napawa fakt, że wśród czynników modyfikowalnych respondenci najczęściej wskazywali palenie tytoniu (57,6\%), otyłość i nadwagę (48,2\%), nieprawidłową dietę i małą aktywność fizyczną (po 42,4\%). Niemniej, respondenci nie utożsamiają występowania choroby z czynnikami niemodyfikowalnymi, takimi jak wiek, płeć czy występowanie choroby w rodzinie [13]. W badaniach Buraczyńskiego i Goliba [14], dotyczących oceny wiedzy pacjentów w fazie rekonwalescencji po zabiegu angioplastyki tętnic wieńcowych na temat eliminacji czynników ryzyka choroby wieńcowej, respondenci nadali rangę niemodyfikowalności takim czynnikom, jak nadciśnienie tętnicze, hipercholesterolemia, nikotynizm czy cukrzyca. Nieprawidłowe wyobrażenie, a tym samym brak pełnej wiedzy w zakresie czynników ryzyka charakteryzuje także respondentów z badania opublikowanego przez Dziedzic i wsp. [15]. Mimo dość dobrego poziomu wiedzy na temat czynników modyfikowalnych - zaburzeń lipidowych, nadciśnienia tętniczego, odżywiania i aktywności fizycznej - respondenci wskazują obciążenie genetyczne, jako element bardziej istotny niż styl życia.

Powyższe doniesienia pokazują niepełną i różnorodną wiedzę pacjentów na temat czynników ryzyka chorób układu sercowo-naczyniowego. W związku z tym przedstawiciele wszystkich profesji medycznych powinni podejmować działania edukacyjne wobec swoich pacjentów. Kwestię eliminacji czynników ryzyka chorób układu sercowo-naczyniowego podkreślili w swojej metaanalizie Berry i wsp. [16]. Naukowcy wykazali niewielkie ryzyko śmierci z powodu incydentu sercowo-naczyniowego do 80. roku życia w grupie pacjentów 55-letnich, u których nie występowały czynniki modyfikowalne, takie jak nadciśnienie tętnicze, hiperlipidemia, cukrzyca, palenie papierosów. Natomiast u pacjentów z dwoma lub więcej czynnikami zagrożenie zgonem wzrastało z 4,7\% do 29,6\% u mężczyzn i z 6,4\% do $20,5 \%$ u kobiet [16].

\section{Metody i środki edukacji zdrowotnej}

W dostępnej literaturze przedmiotu można odnaleźć wiele definicji promocji zdrowia. Najogólniej promocja zdrowia ujmowana jest jako proces, w którym ludzie uczą się dbać o zdrowie własne i innych oraz dokonują wyborów sprzyjających zdrowiu. Pierwsza Międzynarodowa Konferencja w Ottawie (1986), zakończona podpisaniem Karty Ottawskiej, podkreśliła znaczenie promocji zdrowia i wskazała na edukację, jako jej podstawowe narzędzie [17].

Definicja edukacji zdrowotnej zaproponowana przez Joint Committee on Health Education and Promotion Terminology zwraca uwagę na istotę działań edukacyjnych, która polega na nabywaniu przez odbiorców zarówno informacji, jak i umiejętności umożliwiających podejmowanie decyzji zdrowotnych. Wiąże się to nierozłącznie z dokonywaniem 
świadomych wyborów dotyczących zdrowia na podstawie sprawdzonej naukowo wiedzy [18].

Metody edukacji zdrowotnej skupiają się na pacjencie i jego umiejętnościach radzenia sobie z problemami zdrowotnymi, rozumienia współodpowiedzialności za zdrowie oraz wpływie zachowań zdrowotnych i konieczności ich modyfikacji [19].

Edukacja zdrowotna stała się podstawowym elementem postępowania terapeutycznego. Prowadząc edukację, powinno się zwracać uwagę, aby była ona zindywidualizowana, prowadzona przez zespół osób profesjonalnie przygotowanych, które pozostają w stałym i regularnym kontakcie z pacjentem. Powinna ona obejmować specyficzne zagadnienia związane ze zdrowiem oraz wspierając, motywować do zmiany zachowań i wytrwania w podjętych działaniach [20].

Metody edukacji zdrowotnej można podzielić na trzy kategorie: informacyjne, motywacyjne i behawioralne [21]. Metody informacyjne polegają na przekazywaniu pacjentom wiedzy na temat zachowań zdrowotnych, samokontroli i samoopieki zarówno w zdrowiu, jak i w chorobie. Najczęściej wykorzystuje się dwie formy - pisemną i ustną. Narzędziami łatwymi do wykorzystania w placówkach ochrony zdrowia są plakaty, broszury, książki, które nie wymagają dużego zaangażowania ze strony personelu. Przez wzgląd na jednostronny przepływ informacji, rzadko istnieje możliwość zweryfikowania reakcji pacjenta na przekazywane treści. Bez ponownego spotkania nie ma możliwości weryfikacji wiedzy pochodzącej z tego typu źródeł. W przypadku stosowania broszur niezbędne jest odpowiednie zmotywowanie odbiorcy do sięgnięcia po to źródło wiedzy [22]. Interwencje edukacyjne z wykorzystaniem form ustnych to wykłady, porady, pogadanki czy dyskusje. Wykorzystuje się je zarówno przed większym audytorium, jak i podczas indywidualnej interwencji [19].

Zadaniem metod motywujących jest wytworzenie związków między ważnymi życiowymi potrzebami a możliwością ich zaspokojenia. Metody te stosuje się w terapii indywidualnej oraz grupowej. Mogą one być wspomagane materiałami w postaci broszur, plakatów lub filmów. Celem metod motywujących jest wywołanie u odbiorcy emocjonalnych skojarzeń, które mają pomóc w zmianie zachowań i stosowaniu się do zaleceń terapeutycznych. Uważa się, że ulotki i plakaty są skuteczniejsze w zakresie motywowania do zmiany niż broszury, które są głównie nośnikiem wiedzy dla pacjenta [21-23].

Metoda behawioralna polega na wpływaniu na relacje między bodźcami a reakcjami, koncentrując się na wpływie na zachowanie człowieka. Jej celem jest wytworzenie i utrwalenie pożądanych reakcji w postaci prawidłowych zachowań zdrowotnych. Counselling w odniesieniu do czynników behawioralnych definiowany jest jako proces, który pomaga w nabywaniu umiejętności radzenia sobie z problemami interpersonalnymi, decyzyjnymi i emocjonalnymi. Klu- czowym elementem w tej metodzie jest nauczenie pacjenta pewnych umiejętności, dzięki czemu samodzielnie poradzi sobie z problemem. Counselling w edukacji zdrowotnej oznacza pracę z pacjentem, którego rzeczywistość uległa zmianie i musi się on na nowo przygotować do satysfakcjonującego go funkcjonowania w życiu codziennym [19].

Również coaching znalazł swoje zastosowanie w edukacji pacjentów. Jest to proces, który pomaga pacjentowi znaleźć się w nowej, nieznanej do tej pory sytuacji. Coach pomaga zidentyfikować bariery, które uniemożliwiają podjęcie decyzji oraz odnalezienie drogi wyjścia z zaistniałej sytuacji. Cechą charakterystyczną coachingu jest skupienie pełnej odpowiedzialności za podejmowane przez pacjenta decyzje na nim samym, ponieważ coach nie daje gotowych rozwiązań. Skupia on uwage pacjenta na możliwościach dokonania wyboru. Coaching znalazł zastosowanie podczas indywidualnych sesji edukacyjnych w celu samouświadomienia pacjentowi sytuacji, w jakiej się znalazł oraz jako forma wsparcia w trudnych sytuacjach, na które napotyka pacjent w warunkach pozaszpitalnych [24].

Intensywny rozwój nowoczesnych technologii i mass mediów spowodował, że odgrywają one ogromną rolę w życiu, stając się elementem wpływającym na człowieka i społeczeństwo. Środki komunikacji społecznej są w stanie znacząco wpływać na postawy, działania, zachowania i wiedzę o zdrowiu. Upowszechnianie wiedzy o zdrowiu i chorobie stało się jednym z zadań mass mediów. Odbywa się ono poprzez prasę, książki, telewizję, radio oraz internet [25].

\section{Skuteczność podejmowanych działań edukacyjnych}

Działania edukacyjne należą do zadań obligatoryjnych, zarówno w pracy lekarza, pielęgniarki (położnej), fizjoterapeuty, jak i dietetyka. Edukacja zdrowotna stanowi istotny element postępowania terapeutycznego, dlatego powinna odbywać się na każdym etapie pracy z pacjentem - zarówno podczas diagnostyki, leczenia, rehabilitacji, jak i pielęgnacji. Celem interwencji edukacyjnych podejmowanych przez personel ochrony zdrowia jest wyposażenie pacjenta w niezbędny zasób wiedzy, aby mógł on świadomie uczestniczyć w procesie terapeutycznym.

Sawicka i wsp. [26] przeanalizowali stosowanie się do zaleceń aktywności fizycznej, jako elementu zmniejszającego występowanie incydentów wieńcowych w grupie pacjentów po zawale serca i hospitalizacji z powodu choroby wieńcowej. W badaniach wykazano, że większość respondentów (81\%) wskazuje na aktywność fizyczną jako element ważny dla zachowania zdrowia, z czego tylko połowa zadeklarowała regularną aktywność częstszą niż 2 razy w tygodniu. Za czynniki utrudniające podjęcie regularnych ćwiczeń respondenci wskazali kolejno: zły stan zdrowia, brak czasu i brak motywacji. Niepokojący jest fakt, że w badanej grupie $64 \%$ respondentów zmniejszyło 
częstotliwość aktywności fizycznej po wystąpieniu incydentu kardiologicznego [26].

W badaniach Nasser i wsp. [27], przeprowadzonych u 100 pacjentów, wykazano dużą skuteczność w zakresie stosowania się do zaleceń związanych z systematycznym wysiłkiem fizycznym, jako elementem prewencji wtórnej. Program objął poradnictwo zdrowotne w zakresie modyfikacji czynników ryzyka, konsultacje dotyczące ćwiczeń i obserwację telefoniczną. Po dwuletniej obserwacji 88\% pacjentów deklarowało aktywność fizyczną zgodną z zaleceniami [27].

Zadowalające efekty w tym zakresie osiągnęli również Zhao i wsp. [28], którzy w 12-tygodniowej obserwacji poddali grupe 200 pacjentów po incydentach kardiologicznych. Badacze wykazali, że po zastosowanym programie zdrowotnym zwiększył się odsetek pacjentów aktywnych fizycznie w porównaniu z początkowym etapem (z 56\% do 90\% intensywnie ćwiczących) [28].

W metaanalizie opublikowanej w 2013 roku, obejmującej 163 badania, wskazano, że edukacja pacjentów z chorobami przewlekłymi przyczynia się do przestrzegania zaleceń dotyczących ćwiczeń, prowadząc do zwiększenia aktywności fizycznej w zakresie ilości, jakości i długości stosowanych ćwiczeń [29].

Wyniki innego programu stosowanego u pacjentów otyłych wykazały, że po zastosowaniu indywidualnego doradztwa w zakresie żywienia oraz po ustaleniu programu żywieniowego uzyskano redukcję masy ciała oraz poprawę wyników badań lipoprotein w osoczu krwi. Po 12-miesięcznej obserwacji uzyskano wysoki stopień przestrzegania programu i zmniejszenie masy ciała o $5 \%$ u niemal $2 / 3$ pacjentów [30].

W badaniach prowadzonych przez Chan i wsp. [31] w 10 ośrodkach, w grupie 1860 pacjentów kardiologicznych poddanych 12-miesięcznej obserwacji, wykazano znamienny spadek liczby osób palących papierosy po zastosowanym poradnictwie. Edukacją pacjentów zajmowały się pielęgniarki stosujące metodę bezpośredniego poradnictwa trwającego godzinę oraz pozostające w stałym telefonicznym kontakcie z pacjentami [31].

Program edukacyjny realizowany u pacjentów kardiologicznych przez Irmak i wsp. [32], polegający na zastosowaniu grupowej edukacji oraz indywidualnych wizyt domowych w zakresie aktywności fizycznej, zasad żywienia, palenia papierosów i stosowania się do zaleceń terapeutycznych wykazał skuteczność podejmowanych działań we wszystkich aspektach za wyjątkiem przyjmowania leków [32].

Lindsay i wsp. [33] przez 12 miesięcy obserwowali pacjentów ambulatoryjnych leczonych z powodów kardiologicznych. Edukacja odbywała się z wykorzystaniem technologii informatycznych i opierała na indywidualnych konsultacjach oraz grupowych dyskusjach. Omawiane zagadnienia dotyczyły aktywności fizycznej, odżywiania i palenia papierosów. Badania wykazały zwiększenie ak- tywności fizycznej pacjentów, natomiast podjęte działania edukacyjne nie wykazały istotnego wpływu na poprawe w zakresie żywienia i palenia papierosów [33].

Wyniki badania Smith i wsp. [34] wskazują na skuteczność prowadzonej przez pielęgniarki edukacji w zakresie zaprzestania palenia papierosów w grupie pacjentów kardiologicznych. W trakcie prowadzenia edukacji wykorzystywano broszury edukacyjne, indywidualne poradnictwo, filmy i słuchowiska edukacyjne oraz pozostawano w stałym kontakcie telefonicznym z pacjentami. Podjęte działania doprowadziły do zmniejszenia odsetka osób palących po upływie 3, 6 i 12 miesięcy. Pacjenci objęci działaniami edukacyjnymi dwa razy częściej deklarowali podjęcie prób zerwania z nałogiem niż osoby z grupy kontrolnej [34].

Przegląd literatury dotyczącej interwencji edukacyjnej stosowanej wobec pacjentów kardiologicznych dokonany przez Ghist i wsp. [35] wskazuje na edukację jako element wspierający proces terapeutyczny. Pacjenci objęci działaniami edukacyjnymi wykazują wyższy poziom wiedzy oraz charakteryzują się prawidłowymi zachowaniami zdrowotnymi w zakresie diety, aktywności fizycznej i zaprzestania palenia papierosów w porównaniu z respondentami z grup kontrolnych [35].

Prowadzenie edukacji zdrowotnej wśród pacjentów kardiologicznych jest trudnym wyzwaniem dla profesjonalistów ochrony zdrowia. Zależy ono od wielu czynników modyfikowalnych i niemodyfikowalnych. Zasadne wydaje się łączenie różnych metod edukacyjnych przy jednoczesnym doskonaleniu narzędzi oraz wzmacnianiu motywacji pacjenta [36, 37].

Zysnarska i wsp. [38] w badaniach dotyczących zachowań zdrowotnych po przebytym zawale serca wykazali, że najlepszym momentem na wprowadzenie działań edukacyjnych jest czas bezpośrednio po wystąpieniu zawału. Według respondentów doświadczenie związane z wystąpieniem zawału serca było dla nich tak stresującym przeżyciem, że wpłynęło na zmianę zachowań zdrowotnych u $85 \%$ badanych [38].

\section{Podsumowanie}

Edukacja zdrowotna prowadzona na odpowiednim poziomie z zastosowaniem różnych metod i form dydaktycznych przyczynia się do poprawy poziomu zdrowia osób z chorobami układu krążenia, obniżając tym samym koszty leczenia [39]. Biorąc pod uwagę powszechne występowanie chorób układu sercowo-naczyniowego, zasadne wydaje się wprowadzenie działań edukacyjnych na każdym etapie leczenia, w tym także w podstawowej opiece zdrowotnej, których celem jest zapoznanie pacjentów z czynnikami ryzyka i zmotywowanie do zmiany niekorzystnych zachowań zdrowotnych. Edukacja terapeutyczna powinna zajmować priorytetowe miejsce w działaniach leczniczych, dostarcza- 
jąc wiedzy na temat czynników ryzyka, oraz przygotować pacjenta do życia z chorobą i do świadomego uczestniczenia w leczeniu.

\section{Wnioski}

Przedstawione w niniejszym opracowaniu liczne doniesienia naukowe, dotyczące wiedzy pacjentów i skuteczności edukacji prowadzonej wśród chorych stanowią silną przesłankę do podejmowania i doskonalenia działań edukacyjnych oraz wykorzystywania różnych narzędzi w pracy z pacjentem.

\section{Konflikt interesów}

Autorzy nie zgłaszają konfliktu interesów.

\section{Abstract}

Cardiovascular diseases are the main cause of death in Poland and other European Countries. They belong to the group of chronic diseases. Epidemiological studies show that they depends on many modifiable and non-modifiable risk factors. The most important modifiable risk factors are obesity, hyperlipidemia, hypertension, diabetes, smoking, physical inactivity and social factors.

The aim of education of patients with cardiovascular diseases is to eliminate or to modify the existing factors by passing knowledge regarding proper behavior and motivation to follow therapeutic recommendations.

Many studies show that implementation of education with use of oral or writing methods and complex rehabilitation and educational programs favour increase of the knowledge level that may improve the effectiveness of applied therapy.

Key words: health education, cardiovascular disease

Folia Cardiologica 2016; 11, 6: 519-524

\section{Piśmiennictwo}

1. Nichols M., Townsend N., Scarborough P., Rayner M. Cardiovascular disease in Europe 2014: epidemiological update. Eur. Heart J. 2014; 35: 2950-2959.

2. Maroszyńska-Dmoch E.M., Wożakowska-Kapłon B. Choroba wieńcowa w populacji młodych dorosłych: skala problemu, czynniki ryzyka i rokowanie - przegląd literatury. Folia Cardiol. 2014; 3: 267-274.

3. Gierlotka M., Zdrojewski T., Wojtyniak B. i wsp. Incidence, treatment, in-hospital mortality and one-year outcomes of acute myocardial infarction in Poland in 2009-2-12 nationwide AMI-PL database. Kardiol. Pol. 2015; 73: 142-158.

4. Kubica A., Sinkiewicz W., Szymański P., Bogdan M. Edukacja zdrowotna w chorobach układu krążenia - możliwości i zagrożenia. Folia Cardiol. Excerpta 2006; 2 :177-181.

5. Yusuf S., Hawkins S., Ounpuu S. i wsp. Effects of potentially modifiable risk factors associated with myocardial infraction in 52 countries (the INTERHEART study): case control study. Lancet 2004; 364: 937-952.

6. Khawaja F.J., Rihal C.S., Lennon R.J. i wsp. Temporal trends (over 30 years), clinical characteristic, outcomes and gender in patients $<50$ years of age having percutaneous coronary intervention. Am. J. Cardiol. 2011; 107: 668-674.

7. Kubica A., Pufal J., Moczulska B. i wsp. Skuteczność edukacji zdrowotnej u osób hospitalizowanych w klinice kardiologii. Psychiatr. Prakt. Ogólnolek. 2005; 5: 61-68.

8. Kubica A., Jurek A., Olejarczyk E. i wsp. Wybrane czynniki demograficzno-społeczne a skuteczność edukacji zdrowotnej prowadzonej na podstawie broszur edukacyjnych u osób z ostrym zawałem serca. Folia Cardiol. Excerpta 2008; 3: 199-207.
9. Kubica A., Magielski P., Olejarczyk E. i wsp. Źródła wiedzy a skuteczność edukacji zdrowotnej u osób z ostrym zawałem serca. Folia Cardiol. Excerpta 2009; 4: 285-290.

10. Jarząbek K., Kozłowska A., Niedziela J. i wsp. Knowledge of risk factor for coronary artery disease in the population of Lublin and Swietokrzyskie voivodeship in Poland. Folia Cardiol. 2015; 10: 9-16.

11. Mullie P., Clarys P. Association between cardiovascular disease risk factor knowledge and lifestyle. Food Nutri. Sci. 2011; 2: 1048-1053.

12. Kubica A., Pufal J., Moczulska B. i wsp. Ocena wiedzy dotyczącej profilaktyki i objawów choroby niedokrwiennej serca u osób hospitalizowanych w klinice kardiologii. Psychiatr. Prakt. Ogólnolek. 2004; 4: 135-141.

13. Koziński Ł., Krzymińska-Stasiuk E., Głogowska A., Raczak G. Analiza poziomu wiedzy o podstawowych czynnikach ryzyka chorób układu sercowo-naczyniowego z uwzględnieniem zależności społeczno-demograficznych - badanie ankietowe. Folia Cardiol. 2012; 7: 170-176.

14. Buraczyński T., Golib J. Ocena wiedzy pacjentów w fazie rekonwalescencji po zabiegu angioplastyki tętnic wieńcowych na temat eliminowania czynników ryzyka choroby wieńcowej jako elementu prozdrowotnego stylu życia. Med. Ogólna Nauk Zdr. 2014; 20: 199-207.

15. Dziedzic B., Sienkiewicz Z., Zając P., Wiśniewski A. Wiedza pacjentów na temat czynników ryzyka choroby niedokrwiennej serca leczonych w specjalistycznej poradni kardiologicznej. Piel. Zdr. Publ. 2015; 5: 11-19.

16. Berry J.D., Dyer A., Cai X. i wsp. Lifetime risk of cardiovascular disease. N. Engl. J. Med. 2012; 266: 321-329. 
17. Książek P., Herda J., Pawka B. i wsp. Edukacja zdrowotna jako istotny standard w profilaktycznej opiece zdrowotnej nad uczniami w środowisku nauczania i wychowania w województwie lubelskim. Zdr. Publ. 2008; 118: 403-405

18. Gold S.R., Miner R.K. Report of the 2000 Joint Committee on Health Education and Promotion Terminology Am. J. Health Educ. 2001; 32: 89-103.

19. Osińska H. Nowe wyzwania dla edukacji zdrowotnej i promocji zdrowia. Med. Rodz. 2012; 2: 29-35.

20. Sierakowska M., Wrońska I. Edukacja zdrowotna w praktyce pielęgniarskiej. PZWL, Warszawa 2015: 34-37.

21. Szczęch R., Grodzicki T., Narkiewicz K. Edukacja chorych z nadciśnieniem tętniczym. Prom. Zdr. 2001; 8: 7-25.

22. Kubica A. Broszura - narzędzie edukacji zdrowotnej w kardiologii. Przyczynek do dyskusji o skuteczności profilaktyki wtórnej. Folia Cardiol. Excerpta 2008; 3: 441-444.

23. Hellwing D. Skuteczność wybranych środków edukacji zdrowotnej. Med. Ogólna 1995; 1: 324-334.

24. Lewis F.M., Zahilis E.H. The nurse as coach. A conceptual framework for clinical practice. Oncol. Nurs. Forum 1997; 24: 1695-1702.

25. Evans W.D. How social marketing works in health care. BMJ 2006; 332: $1207-1210$.

26. Sawicka K., Łuczyk R., Laska D. Physical activity as a health behavior to reduce risk factor of coronary incidents. J. Health Scien. 2014; 4: 45-68.

27. Nasser A., Shahamfar J., Kumar G.V. Cardiac risk factor changes through an intensive multifactorial life style modification program in CHD patients: results from a two year follow up. J. Biol. Sci. 2008; 8: 248-257.

28. Zhao Y., Wong F.L.Y. Effects of a post discharge transitional care programme for patients with coronary heart disease in China: a randomized controlled trial. J. Clin. Nurs. 2009; 18: 2444-2455.

29. Zhu L.X., Ho S.C., Wong T.K.S. Effectiveness of health education programs on exercise behavior among patients with heart disease: a systematic review and meta-analysis. J. Evid. Based Med. 2013; 6: 265-301.

30. Meffert C., Gardes N. Program adherence and effectiveness of a commercial nutrition program: the metabolic balance study. J. Nutr. Metab. 2010; 2010: 197656.

31. Chan S.S., Leung D.V., Wong D.C. i wsp. A randomized controlled trial of stage matched intervention for smoking cessation in cardiac outpatients. Addiction 2012; 107: 829-837.

32. Irmak Z., Fesci H. Effects of nurse-managed secondary prevention program on lifestyle and risk factors of patients who had experienced myocardial infarction. Appl. Nurs. Res. 2010; 23: 147-152.

33. Lindsay S., Smith S., Bellaby P., Baker K. The health impact of an online heart disease support group: a comparison of moderated versus unmoderated support. Health Educ. Res. 2009; 24: 646-654.

34. Smith P.M., Burgess E. Smoking cessation initiated during hospital stay for patients with coronary artery disease: a randomized controlled trial. CMAJ 2009; 180: 1297-1303.

35. Ghist G.L.M., Abdallah F., Grace S.L. i wsp. A systematic review of patients education in cardiac patients: do they increase knowledge and promote health behavior change? Patient Educ. Couns. 2014; 95: 160-174.

36. Kubica A., Andruszkiewicz A., Grześk G. i wsp. Edukacja zdrowotna jako metoda poprawy programu terapeutycznego. Folia Cardiol. 2010; 5: 93-99.

37. Kubica A. Współpraca z pacjentem - podstawowy warunek skuteczności terapii w chorobie wieńcowej. Choroby Serca i Naczyń 2009; 6: 131-134.

38. Zysnarska M., Jarmuż L., Kara I. i wsp. Wybory w zakresie zachowań zdrowotnych dokonywane przez pacjentów po przebytym zawale mięśnia sercowego. Probl. Hig. Epidemiol. 2014; 95: 488-490.

39. Kubica A., Kochman W., Bogdan M. Wpływ przebytych zabiegów angioplastyki wieńcowej oraz hospitalizacji z powodu zawału serca na poziom wiedzy i skuteczność edukacji zdrowotnej u osób z ostrym zawałem serca. Post. Kardiol. Interw. 2009; 5: 25-30. 